\title{
Two new species of Drosophila belonging to the canalinea group (Diptera, Drosophilidae)
}

\author{
Vilma Ratcov ${ }^{1} \&$ Carlos R. Vilela ${ }^{2}$
}

1. Universidade Braz Cubas, Av. Francisco Rodrigues Filho 1233, 08773-380 Mogi das Cruzes, SP, Brasil. (vilmaratcov@uol.com.br)

2. Departamento de Genética e Biologia Evolutiva, Instituto de Biociências, Universidade de São Paulo, Caixa Postal 11461, $05422-970$ São Paulo, SP, Brasil. (crvilela@ib.usp.br)

\begin{abstract}
Drosophila piratininga sp. nov. and Drosophila sampa sp. nov., belonging to the canalinea group of the subgenus Drosophila, are described based mostly on wild-caught specimens collected at a forest reserve of the Cidade Universitária "Armando de Salles Oliveira", an urban remnant of the montane Atlantic Forest located at west São Paulo city, state of São Paulo, Brazil. The two species are readily distinguished from each other mostly by having different wing patterns: the main crossveins being remarkably clouded in the first one and unclouded in the latter. Illustrations of terminalia are also provided.
\end{abstract}

KEYWORDS. Brazil, Drosophilinae, Neotropical region, São Paulo, terminalia.

RESUMO. Duas novas espécies de Drosophila do grupo canalinea (Diptera, Drosophilidae). Drosophila piratininga sp. nov. e Drosophila sampa sp. nov., espécies neotropicais pertencentes ao grupo canalinea, são descritas no presente artigo. Elas podem ser facilmente separadas com base no padrão das asas, sendo que as duas nervuras transversais são nitidamente esfumaçadas na primeira e hialinas na segunda. As coletas foram realizadas na Reserva Florestal da Cidade Universitária "Armando de Salles Oliveira", um remanescente da Mata Atlântica de planalto localizado na área urbana da zona oeste do município de São Paulo, Estado de São Paulo, Brasil. Ilustrações detalhadas das terminálias são fornecidas.

PALAVRAS-CHAVE. Brasil, Drosophilinae, região Neotropical, São Paulo, terminália masculina.

The Drosophila canalinea species group was proposed by WHEELER (1957) and according to VILELA \& BäCHLI (1990) currently comprises 11 described species: Drosophila albomarginata Duda, 1927; Drosophila annularis Sturtevant, 1916; Drosophila annulosa Vilela \& Bächli, 1990; Drosophila canalinea Patterson \& Mainland, 1944; Drosophila canalinioides Wheeler, 1957; Drosophila davidgrimaldii Vilela \& Bächli, 1990; Drosophila hendeli Vilela \& Bächli, 1990; Drosophila melanoptera Duda, 1927; Drosophila panamensis Malloch, 1926; Drosophila paracanalinea Wheeler, 1957; Drosophila parannularis Vilela \& Bächli, 1990. The group is endemic to the Neotropical region and its species are easily recognized by being mainly dark brown flies with two brown rings on each yellowish tibia and a mesonotum bearing conspicuous dark spots at setae bases, exhibiting a complex pattern of brown and yellow areas, which form diffuse longitudinal stripes (VILELA \& BäCHLI, 1990). Most species are cryptic and the analysis of both the male and female terminalia, especially the shape of the aedeagus and spermatheca, is needed to tell them apart. Specimens of the canalinea group are relatively rare in fruit-baited traps and there are only very few records of success in laboratory culturing. Their larval breeding sites are so far unknown. However, it should be pointed out that the six flies who gave origin to the strain coded H66.7 (University of Texas, Austin), from which the type specimens of Drosophila canalinioides were selected, were collected by W. B. Heed from bracket fungus in El Salvador (WHEELER, 1957). Whether or not this and the remaining species belonging to the canalinea group are associated with fungi in their larval stage is still unknown.

The discovery, in a highly urbanized area, of two undescribed species of the Drosophila canalinea group prompts the present study, and raises to 13 the number of species included in it.

\section{MATERIALAND METHODS}

A total of 12 specimens (4o and 7 , plus one puparium with pupa of undetermined sex) of Drosophila belonging to canalinea group and housed in the Museu de Zoologia da Universidade de São Paulo (MZSP), São Paulo, Brazil, were used in the present study to describe two new species. All but one of the 11 imagoes were collected with an entomological net over open bananabaited traps made of black-painted plastic bottles and hung in bushes at ca. $1 \mathrm{~m}$ above the ground. The exception was one male aspirated on 30.X.1996 from plantlets on the ground, under a trap and most probably attracted to the liquid draining from it. The traps were set in the forest reserve of the Cidade Universitária "Armando de Salles Oliveira", an urban fragment of the montane Atlantic forest of southeastern Brazil located at the western area of São Paulo city, State of São Paulo, Brazil.

Label data attached to each type specimen are cited in full with a slash indicating a label change. Our own notes or interpretations are included in brackets.

For morphological terminology, measurements, indices, preparations of microscope slides as well as illustrations see VILELA \& BäCHLI (1990, 2000) and BäCHLI et al. (2004). 


\section{Drosophila piratininga sp. nov.}

(Figs. 1-14)

Type material. Holotype $\sigma^{7}$ [dissected, middle legs and lower tip of right wing missing] labelled: "Brasil - SP - São Paulo, Reserva da [Forest reserve of] Cidade Universitária, 30.V.1997, Ratcov \& Vilela coll. / Drosophila piratininga Ratcov \& Vilela $\sigma^{7} /$ terminália ilustrada [illustrated terminalia] / HOLOTIPO [HOLOTYPE] / [microvial with terminalia]". Paratypes (20 [both dissected], 79 [three dissected, one of which illustrated]): same data as holotype, except collection dates of the following specimens: o', 28.II.1996, ơ, 30.X.1996, 3ㅇ, 08.XI.1995, 29, 27.II.1996. One additional paratype is a puparium with a pupa of unknown sex (MZSP).

Type locality. Cidade Universitária “Armando de Salles Oliveira”, São Paulo, state of São Paulo, Brazil.

Diagnosis. Body color mainly dark brown; frons velvet reddish brown with one V-shaped, thin, median yellowish area, with poorly defined boundaries, and two triangular paramedian yellow spots at anterior region adjacent to ptilinal suture; mid orbital remarkably nearer to anterior than to posterior one; scutum and scutellum with an irregular mosaic of silvery pollinose spots; wings slightly brownish tinged, anteriorly darker, costal lappet and both main crossveins remarkably clouded.

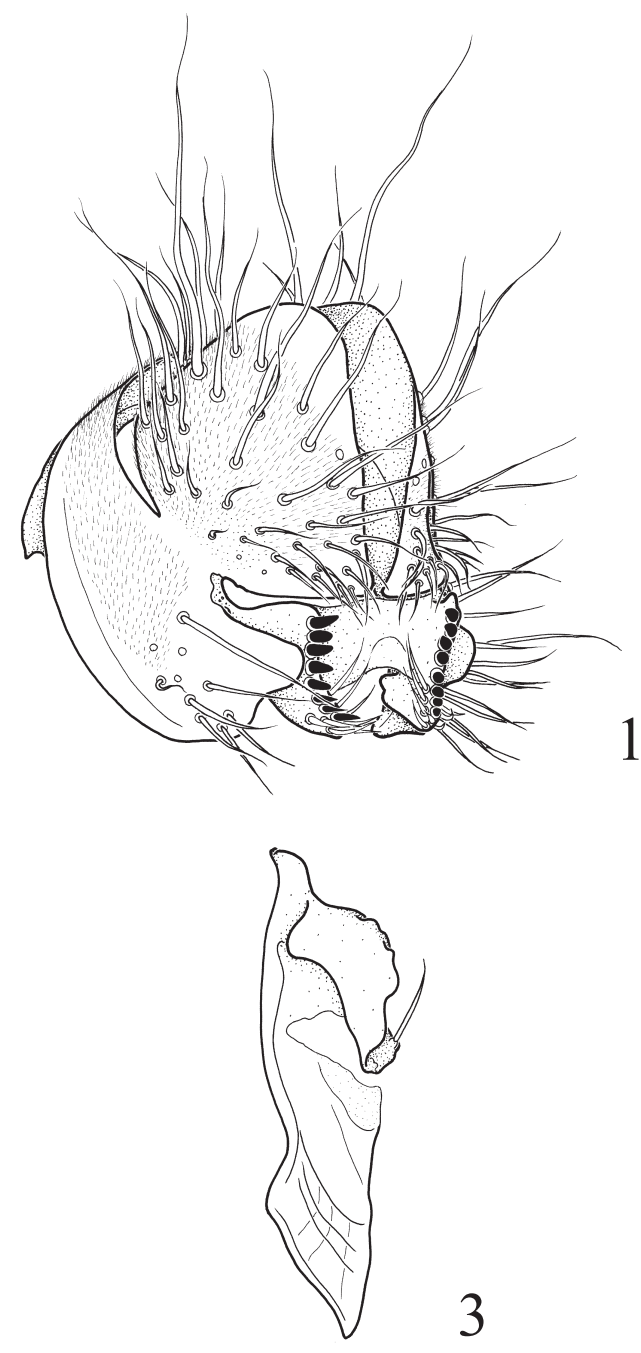

Description. Head brown. Frons generally velvet reddish brown, frontal length $0.37(0.32-0.41) \mathrm{mm}$; frontal index $=0.80(0.75-0.89)$, top to bottom width ratio $=1.39$ (1.29 - 1.50). Frontal triangle brownish grey pollinose, about $97 \%$ of frontal length; ocellar triangle black, about $39 \%$ of frontal length. Orbital plates light greyish, slightly shining, apically divergent from eye margin, about $82 \%$ of frontal length. Orbital setae black, mid orbital distinctly nearer to and somewhat outside of anterior one, or3 to or $1=68 \%$ of that to inner vertical; or $1 /$ or 3 ratio $=0.86$ $(0.73-1.00)$; or $2 /$ or 1 ratio $=0.53(0.44-0.62)$; poc $73 \%$ $(69 \%-79 \%)$, oc $77 \%(69 \%-87 \%)$ of frontal length; vt index $=1.13(1.00-1.25)$; vibrissal index $=0.49(0.25$ $0.67)$; facial carina noselike, slightly sulcate. Gena brown, cheek index about 8 (7.00 - 9.67). Eye index $=1.15$ (1.12 1.25). Pedicel and first flagellomere light brownish; length to width ratio $1.92(1.33-2.50)$. Arista with 5-8 dorsal, 3 ventral and about 5-8 inner branches, plus long terminal fork. Proboscis dark brown.

Thorax dark brown, dorsally with an irregular mosaic of silvery pollinose spots; 7-8 rows of acrostichal setae. $h$ index $=0.89(0.77-1.00)$. Transverse distance of dorsocentral setae $252 \%$ of longitudinal distance; $\mathrm{dc}$ index $=0.70(0.62$ -

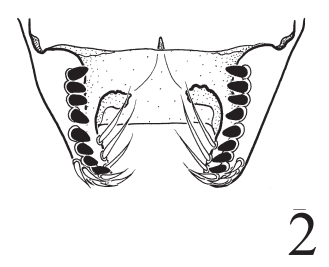

Figs. 1-4. Male terminalia of Drosophila (Drosophila) piratininga sp. nov., holotype: 1, epandrium, cerci, surstyli and decasternum, oblique posterior view; 2, surstyli and decasternum, posterior view; 3, hypandrium and gonopods, left lateral view; 4, idem, ventral view. Bar, $0.1 \mathrm{~mm}$. 
0.78). Prescutellar setae absent. Scutellum prolonged, dark brown, laterally and apically with silvery pollinose spots; distance between apical scutellar setae about $88 \%$ of that of apical to basal one; basal scutellars divergent; scut index $=0.96$ (0.83-1.46). Thorax length: male 1.39 (1.371.44) $\mathrm{mm}$, female $1.48(1.15-1.63) \mathrm{mm}$. Halter yellow. Pleura brownish; sterno index $=0.53(0.48-0.61)$; $\mathrm{mid}$ katepisternal seta about $42 \%$ (18\%-60\%) of the anterior one. Legs yellow, coxae and femora, except tip, dark brown; tibiae with basal and apical dark brown rings; fore tarsi with long recurved setae on inner side.

Wing slightly brownish tinged, anteriorly darker, with remarkably clouded main crossveins, costal lappet clouded; length: male $2.73(2.63-2.80) \mathrm{mm}$, female 2.86 (2.41-3.15) $\mathrm{mm}$; length to width ratio $=2.28(2.16-2.50)$. Indices: $\mathrm{C}=2.15$ (1.96-2.33), $\mathrm{ac}=3.34(3.00-3.78), \mathrm{hb}=$ $0.77(0.74-0.81), 4 \mathrm{C}=1.02(0.93-1.12), 4 \mathrm{v}=1.67(1.56-$ $1.75), 5 \mathrm{x}=0.93(0.81-1.00), \mathrm{M}=0.43(0.39-0.52)$, prox. $\mathrm{x}=$ $0.71(0.62-0.83)$.

Abdomen generally yellowish, tergites 2-6 with a broad, brownish apical band which is medially more-orless narrowed or even interrupted, laterally reaching anterior margin of tergite and bearing an irregular yellowish area.

Male terminalia (Figs. 1-11). Epandrium dorsodistally microtrichose, with ca. 10 lower, and no upper setae; ventral lobe finger-shaped, curved, not microtrichose, partially covering surstylus. Cerci anteriorly fused partially to epandrium, mostly microtrichose and devoid of ventral lobe (Fig. 1). Surstylus (Figs. 1, 2) not microtrichose, bearing a slightly concave row of 8 peglike prensisetae, ca. 4 thin inner and 4 outer setae. Decasternum as in Figs. 1, 2. Hypandrium (Figs. 3, 4) longer than epandrium, anterior margin wide; posterior hypandrial process and dorsal arch absent; gonopod linked to paraphysis by membranous tissue, bearing one seta near the anterior inner margin. Aedeagus (Figs. 511) fused to aedeagal apodeme, dorsally straight, marginally serrate, bent dorsad, and slightly invaginate at tip, ventrally bearing a pair of straight spurs projected anteriorly. Aedeagal apodeme slightly shorter than aedeagus, laterally flattened. Ventral rod absent. Paraphysis bare, medially bent, surpassing tip of spur, and connected to distoventral margin of aedeagal apodeme by membranous tissue.

Female terminalia (Figs. 12-14). Paragenital fringe bearing ca. 19 long setae (Fig. 12). Oviscapt valve apically rounded with ca. 19 marginal and ca. 6 discal peg-like ovisensilla (four most anteriorly ones sharper and thinner) (Fig. 13). Spermathecal capsule (Fig. 14) distally warty, weakly sclerotized, with some sulci at base; basal introvert around half the capsule length; apical introvert absent.

Puparium. Reddish brown; horn index 6.5; each anterior spiracle with 12 branches.

Additional specimen analyzed. A male specimen labelled "Curitiba - PR, 30 / IV / 1993 Moura, M. O. / JB" and deposited in the Departamento de Zoologia da Universidade Federal do Paraná, Curitiba, was brought to one of us (CRV) by M. O. Moura in October 1995 to be identified. Although not used in the above description, and therefore not being considered a paratype, it had been previously dissected. According to some unpublished drawings of its aedeagus made by one of us (CRV), it clearly belongs to Drosophila piratininga sp. nov. and is only being recorded for distribution purposes. This specimen has been cited in the literature (MourA et al., 1997) as Drosophila canalinea group sp., which was collected with an entomological net over laboratory-bred rat carcass (Rattus norvergicus) in a forested site at Curitiba, state of Paraná. Whether or not Drosophila
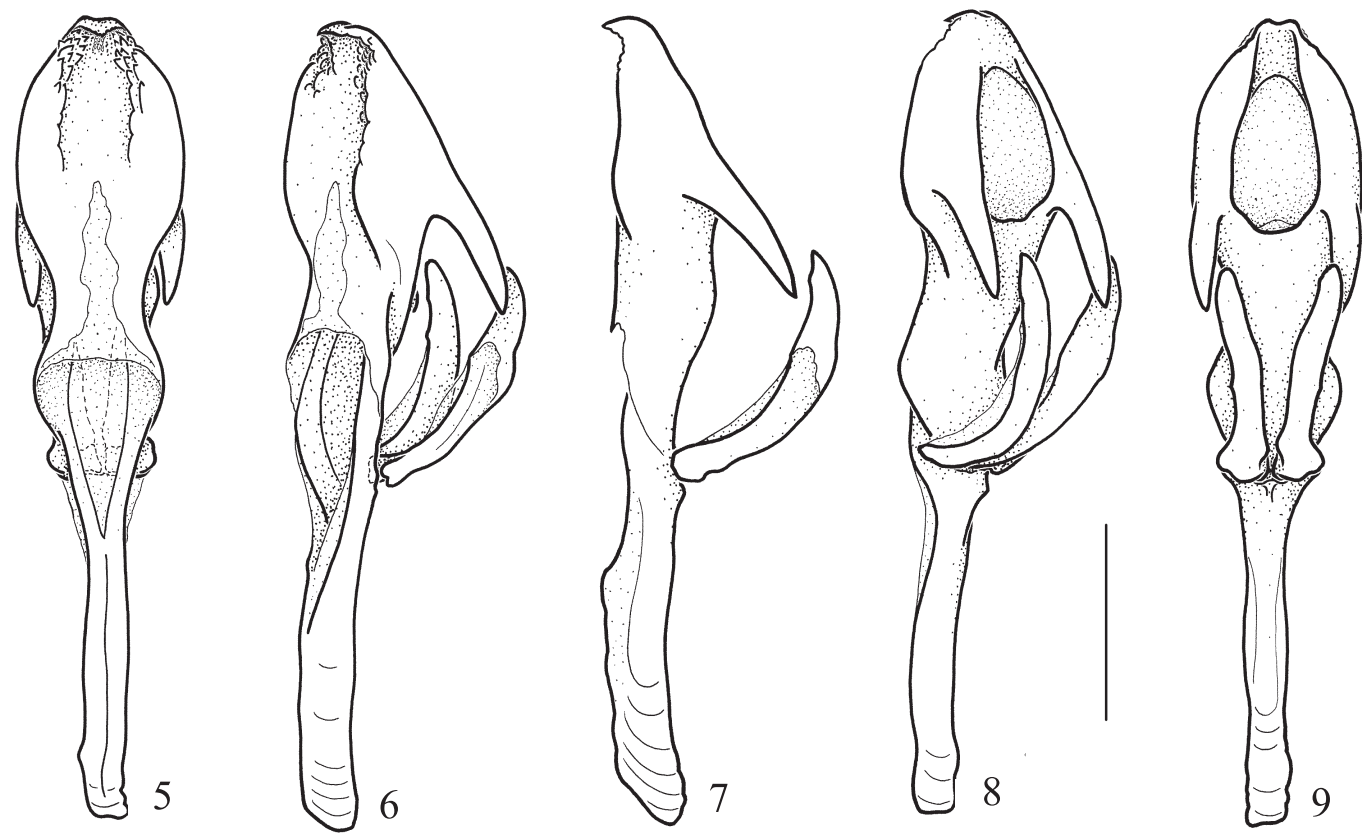

Figs. 5-9. Male terminalia of Drosophila (Drosophila) piratininga sp. nov., holotype: aedeagus+aedeagal apodeme and paraphyses, several views from dorsal through ventral. Bar, $0.1 \mathrm{~mm}$ 

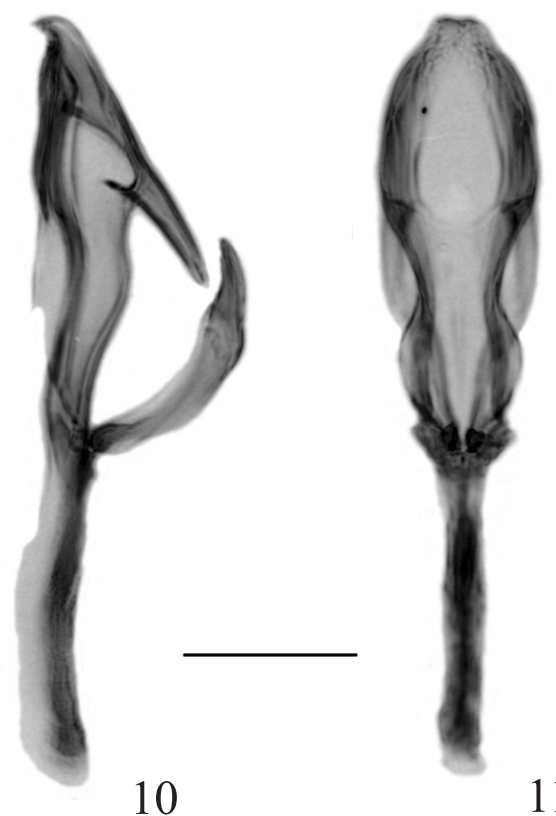

piratininga sp. nov. is a necrophagous species, using carcasses as adult feeding sites and/or larval breeding sites, remains doubtful as this could be just an accidental case.

Distribution. Southeastern (state of São Paulo) and southern (state of Paraná) Brazil.

Etymology. The epithet piratininga is a noun in apposition and an allusion to the ancient name of the type locality (formerly known as São Paulo de Piratininga).

Relationship. It belongs to the canalinea group of the subgenus Drosophila, and is closely related to Drosophila sampa sp. nov., from which it differs mainly by the presence of clouds (absent in Drosophila sampa sp. nov.) along the two main wing crossveins and by having a quite distinct aedeagus.

Note. We were unable to breed these flies on the usual banana-agar culture medium because we have got just one puparium from a mass culture of one male (holotype) and three females, all collected on 30.V.1997, and no imago emerged. The single puparium of the $F_{1}$ generation was double-mounted and is kept together with the remaining of the type specimens.

\section{Drosophila sampa sp. nov.}

(Figs. 15-25)

Figs. 10-11. Photomicrographs of left lateral and dorsal views of aedeagus + aedeagal apodeme and paraphyses of holotype of Drosophila (Drosophila) piratininga sp. nov. Bar, $0.1 \mathrm{~mm}$.

Type material. Holotype ơ labelled: "Brasil - SP - São Paulo, Reserva da Cidade Universitária 28.II.1997 Ratcov \& Vilela coll. / Drosophila sampa Ratcov \& Vilela ơ / terminália ilustrada

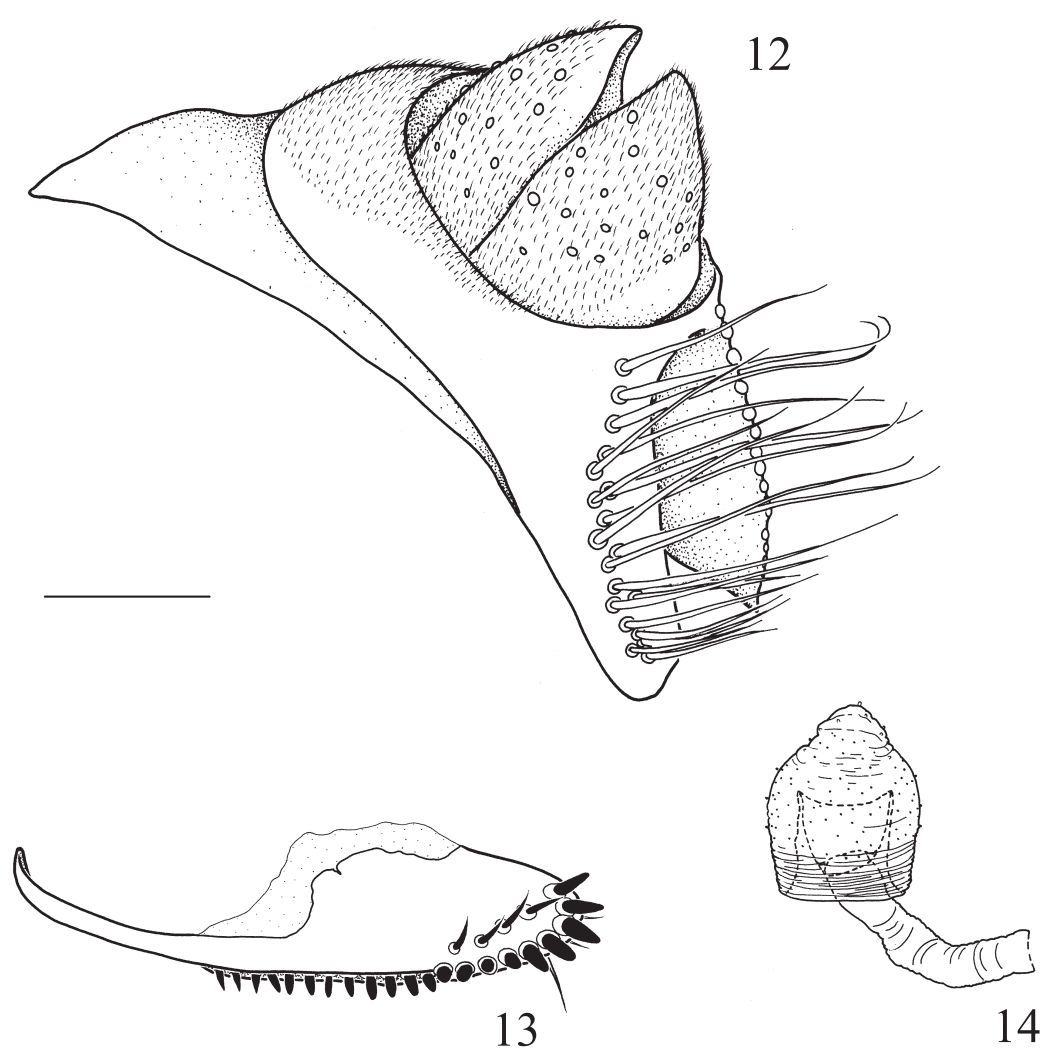

Figs. 12-14. Female terminalia of Drosophila (Drosophila) piratininga sp. nov., paratype: 12, tergite VIII, epiproct and hypoproct, oblique posterior view (setae intentionally omitted in part); 13, left oviscapt valve, left lateral view; 14, inner spermathecal capsule, lateral view. Bar, $0.1 \mathrm{~mm}$. 

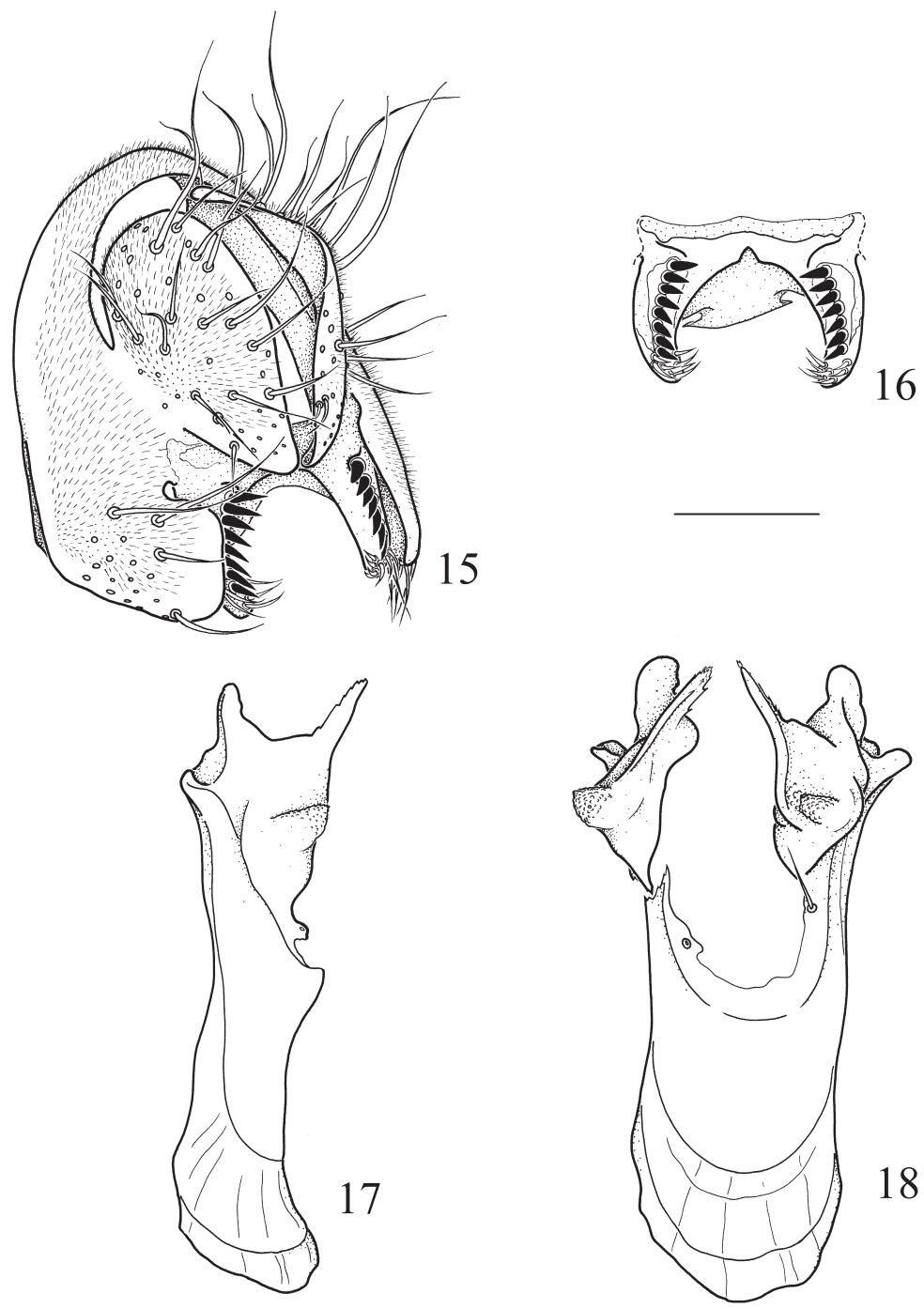

Figs. 15-18. Male terminalia of Drosophila (Drosophila) sampa sp. nov., holotype: 15, epandrium, cerci, surstyli and decasternum, oblique posterior view; 16, surstyli and decasternum, posterior view; 17, hypandrium and gonopods, left lateral view; 18, idem, ventral view (left anterior region accidentally detached). Bar, $0.1 \mathrm{~mm}$.

[illustrated terminalia]/ HOLOTYPE / [microvial with terminalia]" (MZSP).

Type locality. Cidade Universitária "Armando de Salles Oliveira”, São Paulo, state of São Paulo, Brazil.

Diagnosis. Body color mainly dark brown; frons velvet reddish brown with one median, and two paramedian triangular, yellowish areas adjacent to ptilinal suture; mid orbital seta equidistant to anterior and posterior ones; scutum and scutellum with an irregular mosaic of silvery pollinose spots; wings mostly hyaline, $\mathrm{R}_{1}$ bearing three dark brown areas; costal lappet remarkably black, and dilated.

Description. Head brown. Frons generally velvet reddish brown, frontal length $0.37 \mathrm{~mm}$; frontal index = 0.94 , top to bottom width ratio $=1.56$. Frontal triangle somewhat indistinct, distally light brownish, pollinose, about $87 \%$ of frontal length; ocellar triangle black, about $33 \%$ of frontal length. Orbital plates light greyish, slightly shining, apically divergent from eye margin, about $80 \%$ of frontal length. Orbital setae black, mid orbital equidistant to anterior and posterior ones and somewhat outside regarding to them, or 3 to or $1=57 \%$ of that to medial vertical; or $1 /$ or 3 ratio $=0.82$; or $2 /$ or 1 ratio $=0.33$; poc $53 \%$, oc $67 \%$ of frontal length; vt index $=1.09$; vibrissal index $=0.44$; facial carina light pale brown, pollinose, noselike, slightly sulcate. Gena dark brown, cheek index about 8. Eye index $=1.09$. Pedicel and first flagellomere light brownish, medially dark brown; length to width ratio 1.5 . Arista with 5 dorsal, 2 ventral and about 7 inner branches, plus long terminal fork. Proboscis dark brown.

Thorax dark brown, dorsally with an irregular mosaic of silvery pollinose spots; 7 rows of acrostichal setae. $\mathrm{h}$ index $=1$. Transverse distance of dorsocentral setae $243 \%$ of longitudinal distance; $\mathrm{dc}$ index $=0.65$. Scutellum, when seen from back, dark brown, pollinose, and apically silvery; distance between apical scutellar setae about $60 \%$ of that of apical to basal one, basal ones convergent; scut index $=$ ? [broken setae]. Thorax length: $1.2 \mathrm{~mm}$. Halter yellow. Pleura dark brownish; sterno index $=0.62 ; \mathrm{mid}$ 

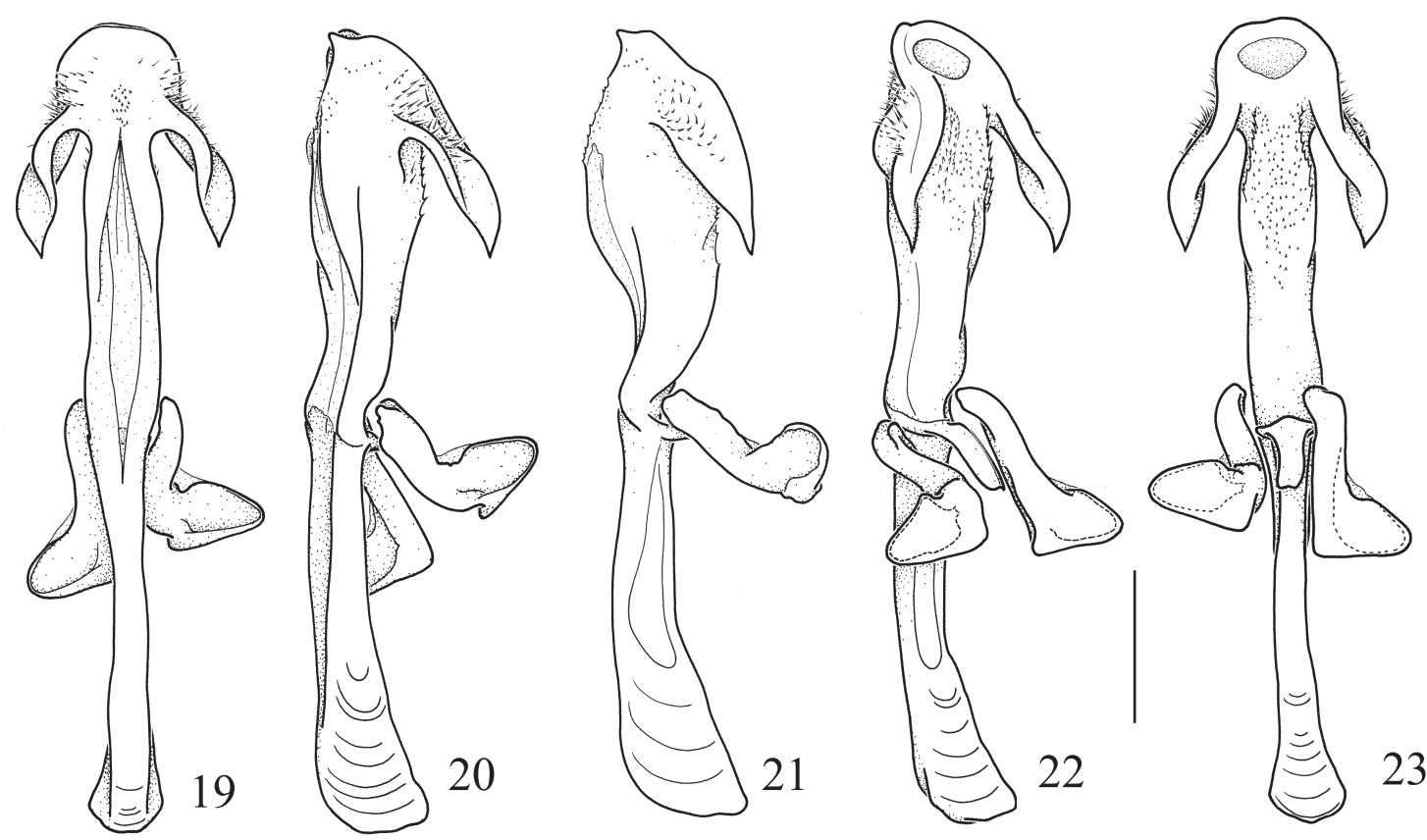

Figs. 19-23. Male terminalia of Drosophila (Drosophila) sampa sp. nov., holotype: aedeagus+aedeagal apodeme and paraphyses, several views from dorsal through ventral. Bar, $0.1 \mathrm{~mm}$.

katepisternal seta about $40 \%$ of the anterior one. Legs proximally dark brown; coxae and femora, except tip, dark brown; tibiae yellow with subbasal and apical dark brown rings; tarsi yellow, fore tarsi with long recurved setae on inner side.

Wing hyaline, apex of first costal section black and twice as wide as its base; length $2.24 \mathrm{~mm}$; length to width ratio $=2.1$. Indices: $C=2.36, a c=3.14, h b=0.68,4 C=0.92$, $4 \mathrm{v}=1.67,5 \mathrm{x}=1.1, \mathrm{M}=0.46$, prox. $\mathrm{x}=0.62$.

Abdomen mostly brownish, tergites 2-6 with a broad, dark brownish apical band which is medially moreor-less narrowed or even interrupted, laterally reaching anterior margin of tergite and bearing an irregular yellowish area.

Male terminalia (Figs. 15-25). Epandrium mostly microtrichose, with ca. 19 lower, and no upper setae; ventral lobe square-shaped, anteriorly microtrichose, partially covering surstylus. Cerci (Fig.15) anteriorly fused partially to epandrium, mostly microtrichose and devoid of ventral lobe. Surstylus (Figs. 15, 16) not microtrichose, bearing a slightly concave row of ca. 8 sharply pointed prensisetae, ca. 4 thin inner and 4 outer setae. Decasternum as in Figs. 15, 16. Hypandrium (Figs. $17,18)$ rectangle-shaped, longer than epandrium; posterior hypandrial process and dorsal arch absent; gonopod mostly fused to hypandrium, posteriorly bifurcate, inner branch dorsally serrate; linked to paraphysis by membranous tissue, bearing one seta near the anterior inner margin. Aedeagus (Figs. 19-25) fused to aedeagal apodeme, dorsally sinuate, distomedially serrate, and slightly bent dorsad in profile (Figs. 21, 24), slightly concave at tip in ventral view (Fig. 23), distally

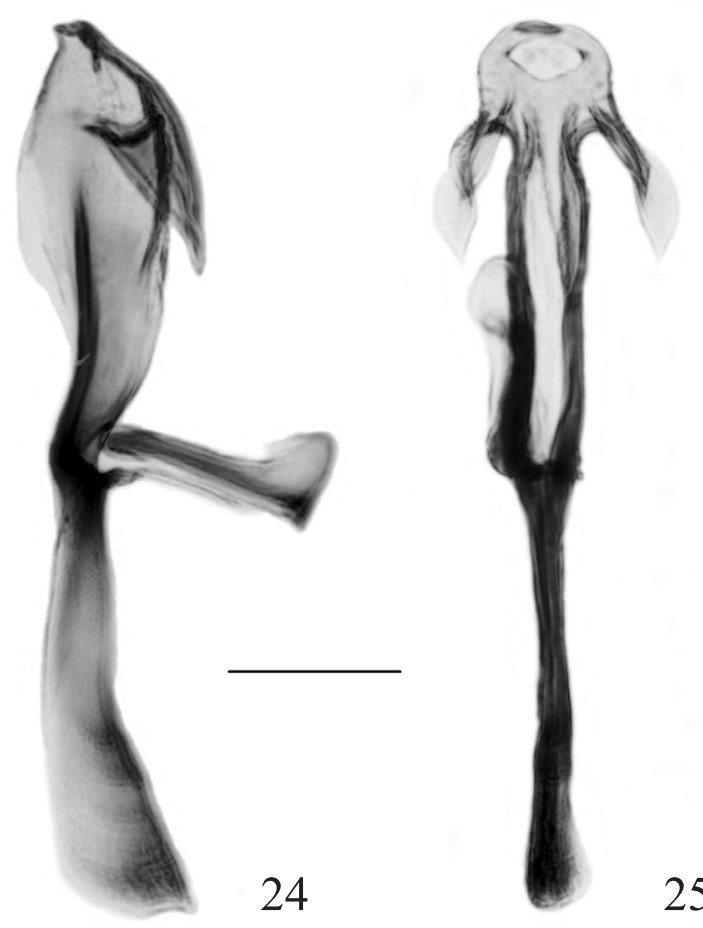

Figs. 24-25. Photomicrographs of left lateral and dorsal views of aedeagus+aedeagal apodeme and paraphyses of holotype of Drosophila (Drosophila) sampa sp. nov. (left paraphysis accidentally detached). Bar, $0.1 \mathrm{~mm}$. 
expanded in ventral and dorsal views (Figs. 19, 23), ventrally bearing a pair of waved, ribbon-shaped (in dorsal and ventral views, Figs. 19, 23, 25), anteriorly projected spurs, medially covered with sharp scales; ventral area between spurs covered with tiny scales (Fig. 23). Aedeagal apodeme as long as aedeagus, anteriorly expanded, laterally flattened. Ventral rod (Figs. 22, 23) half paraphysis length, anteroposteriorly flattened. Paraphysis bare, distally expanded outwards, and connected to distoventral margin of aedeagal apodeme by membranous tissue. Brazil.

Distribution. Southeastern (state of São Paulo)

Etymology. The epithet sampa is a noun in apposition and an allusion to the current nickname of the type locality (São Paulo City).

Relationship. It belongs to the canalinea group of the subgenus Drosophila, and is closely related to Drosophila piratininga sp. nov., from which it differs mainly by the absence of clouds along the two main wing crossveins and by having a quite distinct aedeagus.
Acknowledgments. To two anonymous referees for corrections and suggestions.

\section{REFERENCES}

Bächli, G; Vilela, C. R.; Escher, S. A. \& Saura, A. 2004. The Drosophilidae (Diptera) of Fennoscandia and Denmark. Fauna Entomologica Scandinavica. Leiden, Brill. v. 39, 362p.

Moura, M. O.; Carvalho, C. J. B. DE \& Monteiro-Filho, E. L. A. 1997. A preliminary analysis of insects of medico-legal importance in Curitiba, state of Paraná. Memórias do Instituto Oswaldo Cruz 92(2):269-274.

VILELA, C. R. \& BÄCHLI, G. 1990. Taxonomic studies on neotropical species of seven genera of Drosophilidae (Diptera). Mitteilungen der schweizerischen Entomologischen Gesellschaft 63(suppl.):1-332.

2000. Morphological and ecological notes on the two species of Drosophila belonging to the subgenus Siphlodora Patterson \& Mainland, 1944 (Diptera, Drosophilidae). Mitteilungen der schweizerischen Entomologischen Gesellschaft 73(1-2):23-47.

Wheeler, M. R. 1957. Taxonomic and distributional studies of Nearctic and Neotropical Drosophilidae. University of Texas Publications 5721:79-114. 